\title{
LABOUR SUPPLY IN LATVIA AND ITS IMPACTING FACTORS
}

\author{
Aija Sannikova ${ }^{1}$, Dr.oec., Tamara Grizane ${ }^{2}$, Dr.oec. \\ ${ }^{1}$ University of Economics and Culture, ${ }^{2}$ Turiba University
}

\begin{abstract}
Economic growth in a region affects the demand for labour, including qualified labour. The research analysed changes in the supply of qualified labour and jobs in Latvia. The research revealed that: 1) the supply of jobs by employers increased in the period 2010-2016; 2) the number of vacant jobs also increased in the same period. The research showed that there was a surplus of qualified labour in the national economy of Latvia at the existing output level and supply of jobs. A strong positive correlation was identified between the number of vacant jobs and net earnings $(r=0.80)$. The number of vacant jobs in the period 2010-2016 changed according to a linear trend $(R 2=0.86)$.
\end{abstract}

Key words: supply of labour, qualified labour, vacant jobs, net earnings, regions.

JEL code: O13, O15, R10, R21, R23

\section{Introduction}

The goal of regional policies is to promote balanced and sustainable development of the regions, taking into consideration all the territorial differences and limited opportunities (NDP, 2012). The supply of jobs in the regions by economic sectors as well as the market demand for occupations change dynamically. The economy of Latvia faces considerable problems in its labour market, which is confirmed by a study by the World Economic Forum (World Economic Forum, 2017).

Research aim: to analyse the aspects of labour supply in Latvia. Research tasks: 1) to examine theoretical findings on labour supply problems and the role of labour supply in the economy and society; 2) to analyse the aspects of labour supply in Latvia in the context of changes in the number of qualified labour and the earnings level.

\section{Research methods:}

The research employed qualitative methods for theoretical literature review, while numerical data were processed using statistical analysis and correlation analysis.

Research sources and materials: the Central Statistical Bureau, the Ministry of Economics, documents, statistics and research studies from Latvia and international organisations.

Research limitations. The present research defines the following terms as follows: 1) qualified residents - individuals (aged 15-74) who have higher education (International Standard Classification of Education (ISCED) levels 5-8) and secondary professional education (ISCED levels $3-4)$; 2) knowledge - an aggregate of: knowledge, skills and competences; 3) qualified workforce employed and unemployed individuals (aged 15-74) with higher and secondary professional education.

\section{Theoretical background Role of labour supply in the national economy}

In the post-crisis period (after 2010) in Latvia, the demand for qualified labour in the economic sectors increased owing to growth in economic activity and entrepreneurial development (Ministry of Economics, 2016). Consequently, the employment rate in Latvia was 9.6 percentage points higher in 2016 than in 2010.

Nevertheless, labour is limited in any economy: 1) absolutely - in this case the supply of labour in a region is limited due to the limited number of working-age population; 2) relatively - due to the factors that can affect and change the supply of labour and the demanded quality of labour. Besides, the quantitative supply of labour increases if the knowledge of the working-age population earns adequate economic returns in the market of the factors of production (Sannikova A., 2014). 
The lack of labour in the economy of Latvia becomes an increasingly urgent problem. The largest lack of labour in Latvia is observed in manufacturing, Information and Communication Industries (Ministry of Economics, 2016), yet professional associations believe that the problem with the availability of labour is specific to all industries, and $53.8 \%$ enterprises face the lack of it (LETA, 2017).

Entrepreneurs see solutions to a mismatch between vacant jobs and unemployed labour mainly in education exports ( $91 \%$ ), and, to a smaller extent, in the integration of the unemployed into the labour market (6.7\%), (LETA, 2017). However, the vector of debates by the government and politicians in Latvia is oriented towards highly qualified labour (Saeima, 2002; Ministry of Economics, 2017; LETA, 2018; Cabinet of Ministers, 2017). The problem is that the factors causing a mismatch between labour supply and demand are little researched; besides, providing priorities for highly qualified foreign specialists in relation to remuneration could negatively affect the competitiveness environment for national labour resources.

Undeniably, the engagement of highly qualified labour in the economy contributes to the transfer and transformation of knowledge and fosters sustainable economic growth (Carayannis, E., Campbell D., 2012), as the knowledge is built up in multifaceted institutional processes, but at different levels (Warhust Cr., Thompson P. , 2012).

Economic returns from labour could be a significant factor in household decisions on labour supply, as there are a few convincing research studies proving the positive effect of low earnings on employment among broad social groups. Besides, an increase in the earnings level in a region negatively affects employment opportunities for low qualification employees (Goldfarb, 1974). This fact makes the discussion urgent, as intensive economic globalisation increasingly contributes to the dominance of highly qualified labour over low qualified labour. For this reason, the only way how to reduce social tension caused by unemployment and escape the trap of low qualification in the regions is to contribute to the knowledge of those being at the bottom of this distribution (Brown Ph., Lauder H, Ashton, Z., 2012). An additional argument is the insufficient use of high knowledge at modern jobs (Allen J., Velden R., 2009) and paid labour management problems (Livingstone D., Guile D., et al., 2012).

Even though human capital theoreticians argue that investment in education results in changes in the work environment and lead to economic growth (McKenzie P. ,2001; David P. , Foray D., 2002; Young M., 2012), the role of knowledge in the concept of modern economy and political discussions increases (Gradstein M. et al., 2005; Dumciuviene D., 2015); therefore, the knowledge and education possessed by individuals has to be persistently enhanced. Nevertheless, it has to admitted that it does not avoid a situation where those with higher education get unemployed.

Growing demand for knowledge at jobs is the background of a knowledge economy, and the goal of governments is to ensure that labour possesses knowledge that is demanded in the labour market (European Commission, 2016). Unoccupied job vacancies indicate that the labour market functions ineffectively, and the reasons are that labour supply does not match labour market needs and employment terms offered are inadequate, e.g. the earnings level. Accordingly, the supply of jobs and the supply of labour in the regions have to be analysed to tackle the problems of unemployment and unoccupied vacancies. 


\section{Research results and discussion}

The availability of qualified labour is affected by changes in the number of qualified residents; therefore, the present research focused on this aspect. As demographic changes in Latvia were negative in the period 2010-2016 (decrease by 11.0\%) (CSB, 2018b), the total number of qualified residents aged 15-74 decreased by 16.1 thousand. The decrease in the number of qualified working-age residents in Latvia was reported in all the regions, except for Pieriga region (Table 1). In Pieriga region, the number of qualified residents aged 15-74 increased by 9.9 thousand in 2016 compared with 2010. In contrast, in the same period in Kurzeme it decreased by 10.2 thousand, while the smallest decrease was reported in Latgale region (1.6 thousand). One can conclude that there were negative trends in the field of quality of human resources in the period 2010-2016.

In 2016, the highest proportion of qualified residents aged 15-74 in the total population was reported in Riga region - 66.8 percent ( 316.8 thousand individuals), whereas the lowest proportions were in Kurzeme region (90.9 thousand; $49.8 \%$ ) and Zemgale region (86.9 thousand; $49.78 \%$ ) (Table 1 ).

However, the proportion of qualified residents in Latvia in 2016 compared with 2010 tended to increase (by 6.0 percentage points). The largest increases in the proportion were reported in Pieriga region (7.3 percentage points) and Latgale region (8.3), while the smallest increases were reported in Kurzeme region (2.8 percentage points), Zemgale region (3.8) and Vidzeme region (3.9).

Percentage distribution of residents aged $15-74$ by education level and by region in Latvia in 2010 and 2016

\begin{tabular}{|c|c|c|c|c|c|c|c|c|c|c|c|c|c|}
\hline \multirow{3}{*}{ No } & \multirow{3}{*}{ 음 } & \multicolumn{4}{|c|}{$\begin{array}{c}\text { Residents by education } \\
\text { level, \%* }\end{array}$} & \multicolumn{4}{|c|}{$\begin{array}{c}\text { Residents by education } \\
\text { level, \%* }\end{array}$} & \multirow[t]{2}{*}{ QP } & \multirow[t]{3}{*}{ QP, \% } & \multirow{2}{*}{\multicolumn{2}{|c|}{$\begin{array}{c}2016 / \\
2010\end{array}$}} \\
\hline & & A & B & C & D & A & B & C & D & & & & \\
\hline & & \multicolumn{4}{|c|}{2010} & \multicolumn{5}{|c|}{2016} & & $\mathbf{N}$ & $\mathbf{P}$ \\
\hline 1 & $\mathrm{R}$ & 46.3 & 30.1 & 31.8 & 20.4 & 45.3 & 45.3 & 29.5 & 31.6 & 316.8 & 66.8 & -2.6 & 5.8 \\
\hline 2 & PR & 18.3 & 17.1 & 18.8 & 16.5 & 20.5 & 20.5 & 17.6 & 18.4 & 162.5 & 60.2 & 9.9 & 7.3 \\
\hline 3 & $\mathrm{~K}$ & 9.9 & 12.9 & 12.8 & 17.4 & 8.7 & 8.7 & 12.5 & 15.0 & 90.9 & 49.8 & -10.2 & 2.8 \\
\hline 4 & Z & 8.9 & 11.7 & 12.7 & 15.9 & 8.6 & 8.6 & 11.6 & 13.4 & 86.9 & 49.7 & -4.8 & 3.8 \\
\hline 5 & V & 6.9 & 11.3 & 9.8 & 12.7 & 6.6 & 6.6 & 10.9 & 9.1 & 75.5 & 53.1 & -6.7 & 3.9 \\
\hline 6 & $L$ & 9.9 & 17.0 & 14.1 & 17.1 & 10.2 & 10.2 & 17.8 & 12.7 & 120.9 & 59.2 & -1.6 & 8.3 \\
\hline 7 & $\mathrm{~T}$ & 100 & 100 & 100 & 100 & 100 & 100 & 100 & 100 & 853.5 & 58.9 & -16.1 & 6.0 \\
\hline
\end{tabular}

Designations: $R$ - Riga region; PR - Pieriga region; K-Kurzeme region; Z- Zemgale region; V-Vidzeme region; L- Latgale region; $A$ - higher education (ISCED levels 5-8); $B$ - secondary professional education (ISCED levels 3-4); C- secondary education (ISCED level 3), B-primary education (ISCED levels 1-2), T-total; QP- number of qualified residents in a region; thou.; QP, \%- number of qualified residents as a \% of total residents in a region; \%* - number of residents as a \% of the total group of residents with corresponding education in a region; 2016/2010 - change in the percentage of qualified residents in 2016 compared with 2010; $N$ - change in the number of qualified residents in 2016 compared with 2010; $P$ - change in the percentage of qualified residents, 2016/2010, percentage points.

Source: authors' calculations based on CSB, $2018 b$

A balance between demand and supply in the labour market results in jobs being occupied, yet unused labour resources in the economy indicate the supply of unemployed labour. The calculations showed that in the period 2010-2016 in Latvia among residents aged 15-74 (Table 2): 1) a decrease in the number of the unemployed was very significant - 105.5 thousand (54\%); 2 ) the number of the unemployed decreased in all the regions of Latvia, yet the largest decrease was registered in Riga region (by 53.6 thousand); 3) the proportion of the qualified unemployed in the total number of the unemployed was high in Latvia: $48.9 \%$ in 2010 and $49.0 \%$ in 2016. 
The decrease in the number of the unemployed in Latvia was affected by at least two factors: 1 ) increase in employment; 2) demographic situation. In 2016 compared with 2010 in Latvia, the number of the employed rose by $5 \%$ ( 42.6 thousand), whereas the number of the unemployed declined by $53.7 \%$ (110.5 thousand) (CSB, 2018b), which indicates that the effect of the increase in employment on the decrease in unemployment was not crucial. A much more significant effect was caused by a decrease in the population of Latvia at working-age in all age groups (15-24, 2539 and 40-64 years), although at various rates (Sannikova A., Grizane T., Dobele A., 2017). One can assume that the decrease in the number of the unemployed was affected by other factors as well, e.g. emigration in search of employment to other EU Member States or beyond this region (CSB, 2018a).

A high proportion of qualified residents both in the total number of the unemployed and in the total number of economically inactive population indicate considerable labour resource reserves in the economy, the involvement of which in economic activity could increase output (Dubra E., 2008). In 2016, the greatest lost opportunities for qualified labour existed in Latgale region $56.1 \%$ qualified unemployed residents had no jobs (Table 2 ). In the other regions of Latvia, too, the lost opportunities for qualified labour could be rated as high: in the regions of Pieriga and Riga, more than half of the unemployed were qualified individuals.

Distribution of unemployed and economically inactive residents aged 15-74 by region in Latvia in 2010 and 2016

\begin{tabular}{|c|c|c|c|c|c|c|c|c|c|c|c|}
\hline \multirow{3}{*}{ No } & \multirow{3}{*}{ 兽 } & \multicolumn{4}{|c|}{2010} & \multicolumn{4}{|c|}{2016} & \multirow{2}{*}{\multicolumn{2}{|c|}{$\begin{array}{l}2016 / 2010 \\
\text { Unemployed }\end{array}$}} \\
\hline & & \multicolumn{2}{|c|}{ Unemployed } & \multicolumn{2}{|c|}{$\begin{array}{c}\text { Economically } \\
\text { inactive }\end{array}$} & \multicolumn{2}{|c|}{ Unemployed } & \multicolumn{2}{|c|}{$\begin{array}{l}\text { Economically } \\
\text { inactive }\end{array}$} & & \\
\hline & & $\mathbf{N}$ & $\%$ & $\mathbf{N}$ & $\%$ & $\mathbf{N}$ & $\%$ & $\mathbf{N}$ & $\%$ & $\mathbf{N} *$ & PR* \\
\hline 1 & $R$ & 79.3 & 54.9 & 162.4 & 41.8 & 25.7 & 52.5 & 139.2 & 47.1 & -53.6 & -2.3 \\
\hline 2 & PR & 33.0 & 46.4 & 101.7 & 34.2 & 12.0 & 52.5 & 82.0 & 42.9 & -21.0 & 6.1 \\
\hline 3 & K & 21.5 & 47.0 & 80.2 & 29.7 & 11.8 & 40.7 & 62.1 & 29.6 & -9.7 & -6.3 \\
\hline 4 & Z & 28.6 & 36,0 & 72.7 & 27.1 & 14.1 & 36.9 & 57.2 & 33.2 & -14.5 & 0.9 \\
\hline 5 & $\mathrm{~V}$ & 15.5 & 38,1 & 66.7 & 30.4 & 8,6 & 45.3 & 49.1 & 34.4 & -6.9 & 7.3 \\
\hline 6 & $\mathrm{~L}$ & 27.9 & 55.9 & 95.2 & 32.0 & 23.1 & 56.3 & 72.1 & 40.9 & -4.8 & 0.4 \\
\hline 7 & Total & 205.8 & 48.9 & 578.9 & 34.0 & 95.3 & 49.0 & 461.7 & 40.0 & -105.5 & 0.1 \\
\hline
\end{tabular}

Designations: $N$ - number; $R$ - Riga region; $P R$ - Pieriga region; K-Kurzeme region; Z- Zemgale region; V-Vidzeme region; LLatgale region; \% - number of the qualified unemployed as a \% of the total unemployed; $2016 / 2010$ - change in 2016 compared with 2010; $N^{*}$ - change in the number of the unemployed in 2016 compared with 2010; PR*- change in the proportion of qualified residents in the total unemployed residents in 2016 compared with 2010, percentage points.

Source: authors' calculations based on CSB, $2018 b$

The present research seeks to identify whether the qualified unemployed (or part of them) could be potentially employed, given the existing supply of labour. For this reason, the research analyses data on the supply of labour in Latvia as a whole and on unoccupied vacancies.

In the period 2010-2016 in Latvia, the supply of jobs consisted of main jobs, additional jobs and unoccupied vacancies (Table 3). The total number of jobs supplied in Latvia in 2016 compared with 2010 rose by $15.1 \%$. Supply dominated over demand in the labour market, yet in 2016 compared with 2010 the number of main jobs decreased by $8.0 \%$. Besides, the proportion of main jobs in the total occupied jobs gradually decreased in the period 2010-2016. This could indicate the fact that employers started offering more part-time jobs, while employees probably wished to work for several employers.

A vacant job is defined as a job, for which no individual has been selected and no employment contract has been concluded, and the employer actively searches for an appropriate individual 
outside the work team and is ready to fill the vacancy immediately or in the nearest future. An analysis of the data shows that the number of vacancies in Latvia in the period 2010-2016 gradually rose and in 2016 the number of job vacancies reached 14.4 thousand (compared with 2010 , an increase by 7.7 thousand or $119.4 \%$ ).

Unoccupied vacancies indirectly indicate the following: 1) labour does not match employer requirements; 2) poor cooperation among education professionals, responsible officials of the Ministry of Education and Science, employers and other social partners in relation to labour skill development policies.

\section{Numbers of occupied and vacant jobs and the number of the qualified unemployed in Latvia in 2010 and 2016}

\begin{tabular}{|l|c|c|c|c|c|c|c|c|c|}
\hline No & Indicator & $\mathbf{2 0 1 0}$ & $\mathbf{2 0 1 1}$ & $\mathbf{2 0 1 2}$ & $\mathbf{2 0 1 3}$ & $\mathbf{2 0 1 4}$ & $\mathbf{2 0 1 5}$ & $\mathbf{2 0 1 6}$ & Change, 2016/2010, \% \\
\hline 1. & A & 776.7 & 805.5 & 839.1 & 865.1 & 874.6 & 883.7 & 887.3 & 14.2 \\
\hline 2. & B & 646.2 & 672.8 & 696.9 & 715.6 & 712.9 & 631.8 & 594.2 & -8.0 \\
\hline 3. & C & 83.2 & 83.5 & 83.1 & 82.7 & 81.5 & 71.5 & 67.0 & - \\
\hline 4. & D & 6.7 & 10.1 & 11.4 & 13.5 & 12.3 & 13.2 & 14.4 & 114.9 \\
\hline 5. & E & 783.4 & 815.6 & 850.5 & 878.6 & 886.9 & 896.9 & 901.7 & 15.1 \\
\hline 6. & F & 103.7 & 79.2 & 76.4 & 59.0 & 53.0 & 50.3 & 46.7 & -55.0 \\
\hline 7. & G & $\mathbf{- 9 7 . 0}$ & $\mathbf{- 6 9 . 1}$ & $\mathbf{- 6 5 . 0}$ & $\mathbf{- 4 5 . 5}$ & $\mathbf{- 4 0 . 7}$ & $\mathbf{- 3 7 . 1}$ & $\mathbf{- 3 2 . 3}$ & $\mathbf{- 6 6 . 7}$ \\
\hline $\mathbf{8 .}$ & H & 15 & 8 & 7 & 4 & 4 & 4 & 3 & - \\
\hline
\end{tabular}

Designations: A- average number of occupied jobs a year, thou.; B-average number of occupied main jobs a year, thou.; $C$ average number of occupied main jobs a year as a \% of total; $D$ - average number of vacant jobs a year, thou.; $E$ - average number of available jobs a year, thou.; F- number of the qualified unemployed; G-difference between the number of vacant jobs and the number of the qualified unemployed; $\mathrm{H}$ - number of qualified employees per vacant job, ratio; change $2016 / 2010$, \%.

Source: authors' calculations based on CSB, $2018 \mathrm{~b}$

The lowest performance indicators for Latvia, according to the World Economic Forum report (World Economic Forum, 2017), with regard to labour market flexibility were as follows: 1) country capacity to retain talent $\left(118^{\text {th }}\right.$ position, score 2.6$\left.) ; 2\right)$ country capacity to attract talent $\left(118^{\text {th }}\right.$ position, score 2.4). The failure to engage qualified labour resources in the economy is one of the examples that relates to the mentioned findings.

A further analysis is based on an assumption that every vacancy may be occupied by only one qualified individual. The calculations revealed that in 2010 in Latvia, there were, on average, 15 qualified unemployed residents per vacancy, while in 2016 - only three (Table 3). A decrease in competition for jobs in the labour market reduces employer opportunities to find an appropriate employee.

The calculations showed that at the existing number of vacancies and supply of labour and assuming that the qualified unemployed wished and were able to fill vacancies, there would be a surplus of qualified labour in the period 2010-2016 anyway (Table 3). In 2016, the theoretical surplus of qualified labour would be equal to 32.3 thousand employees (besides, in reality a surplus of low qualified labour should be added to this number). Accordingly, to tackle problems in the labour market, discussions among the social partners have to be encouraged with the purpose of exploiting national labour resources more effectively in the national economy.

The factors that affect the situation - vacancies are not filled - relate to a mismatch among labour market requirements, employment terms and individual preferences of potential employers. Even though wage and salary formation flexibility in Latvia is rated high (World Economic Forum, 2017), it still significantly affects the supply of labour by households (CV-Online, 2017). 
To identify a causal association between the number of vacancies (dependent variable) and the net earnings level (independent variable), the research performed a correlation analysis. The research used the available data for the period 2009-2016. The correlation analysis showed that at a probability of $95 \%$, there was a strong positive relationship $\left(r=0.80 ; r_{0.05} ; 9=0.666<r\right)$. This allows concluding that the supply of labour by households in the market of the factors of production was affected by economic returns from labour. This conclusion is consistent with the findings of a survey (CV-Online, 2017), in which in $26 \%$ instances net earnings were referred to as the key factor in the choice of a job.

To identify a trend in the number of vacancies in Latvia, the research did a regression analysis. The analysis revealed that in the period 2010-2016 in Latvia the number of vacancies had a linear trend $\left(R^{2}=0.86\right),(1)$ :

$$
y=1111 x+7256.6(1)
$$

where:

$x$ - period $(x=t+n), R$ - determination coefficient.

\section{Conclusions}

- The supply of labour and the factors affecting it are broadly discussed in the scientific and public arenas, stressing the roles of qualified labour, education and job transformation in the modern work environment.

- In Latvia, the supply of labour by households in 2016 compared with 2010 increased $(15.1 \%)$, yet part of the jobs offered were not occupied - in 2016 there were 14.4 thousand vacancies. The number of vacancies in Latvia in the period 2008-2016 changed according to a linear trend $\left(R^{2}=0.86\right)$.

- In Latvia, the number of the unemployed in 2016 compared with 2010 decreased by 105.5 thousand, while the proportion of the qualified unemployed in the total number of the unemployed in 2016 was 0.1 percentage points lower than that in 2010.

- The calculations showed that at the existing supply of jobs and assuming that all the jobs are occupied, which is a theoretical assumption, there would be a surplus in the supply of qualified labour in the economy of Latvia in the period 2010-2016. For this reason, the expected involvement of foreign labour in the national economy of Latvia over the next years could increase the theoretical surplus of labour resources at the existing production and resource use level.

- An essential factor in the supply of labour is the earnings level, and it affects the number of vacancies. There was a positive strong correlation between the number of vacancies and the net earnings level $\left(r=0.80 ; r_{0.05 ; 9}=0.666<r\right)$.

\section{Bibliography}

1. Allen, J., Velden, R. (2009) Report on the Large-Scale Graduate Survey: Competencies and Early Labour Market Careers of Higher Education Graduates. Lifelong Learning Programme, European Commission. Retrieved: http://www.hegesco.org/content/view/36/108/. Access: 06.01.2018.

2. Brown, Ph., Lauder H, Ashton's, Z. (2011). The Global Auction: The Broken Promises of Education, Jobs, and Incomes. Oxford /New York, NY, Oxford University Press, 2011. Socio-Economic Review, Volume 10, Issue 4, 1 October 2012, pp. 779-793. Retrieved: https://academic.oup. com/ser/article-

abstract/10/4/779/1631999; http://www.thedivineconspiracy.org/Z5259T.pdf. Access: 10.12.2017.

3. Cabinet of Ministers of the Republic of Latvia (2017). Cabinet Regulation (draft). List of Specialities (professions) in which a Significant Lack of Labour is Expected and in which Foreign Labour may be Employed in the Republic of Latvia. Retrieved: http://tap. mk.gov.lv/lv/mk/tap/?pid=40425903. Access: 17.12.2017. 
4. Carayannis, E., Campbell, D. (2012). Mode 3 Knowledge Production in Quadruple Helix Innovation Systems. 21st-Century Democracy, Innovation, and Entrepreneurship for Development. Retrieved: http://www.springer.com/gp/book/9781461420613. Access: 16.12.2017.

5. Central Statistical Bureau (CSB) (2017). Latvia. Key Statistical Indicators 2017. Riga, p. 83. Retrieved: http://www.csb.gov.Iv/sites/default/files/nr_03_latvija_galvenie_statistikas_raditaji_2017_17_00_lv.pdf. Access: 03.01.2018.

6. Central Statistical Bureau (CSB) (2018a). Emigrant's Profile in 2014-2016. Retrieved: http://www.csb.gov.Iv/sites/default/files/emigranta_portrets_2014_2016_gadaa.pdf. Access: 28.01.2018.

7. Central Statistical Bureau (CSB) (2018b). Statistical database. Retrieved: http://www.csb.gov.Iv/dati/statistikas-datubazes-28270.html. Access: 30.01.2018.

8. CV-Online Latvia (2017). Survey: Motivating Factors for Employers. Retrieved: https://www.cv.lv/content/index.php?id=1456. Access: 01.02.2018.

9. David P. A., Foray D. (2002). An Introduction to the Economy of the Knowledge Society. International Social Science Journal, Vol. 54, No. 171, pp. 9-23.

10. Dubra E. (2009). Social and Methodological Aspects of Latvian Labour Market Research. University of Latvia proceedings, Vol. 737. Economics, VII, pp. 100-111.

11. Dumciuviene D. (2015). The Impact of Education Policy to Country Economic Development. Procedia Social and Behavioural Sciences. Volume 191, pp. 2427-2436. Retrieved: http://www.sciencedirect.com/science/article/pii/S187704281502562. Access: 26.08.2015.

12. European Commission (2016). Europe 2020 Strategy. Retrieved: https://ec.europa.eu/info/businesseconomy-euro/economic-and-fiscal-policy-coordination/eu-economic-governance-monitoring-preventioncorrection/european-semester/framework/europe-2020-strategy_en. Access: 10.12.2017.

13. Goldfarb, R. (1974). The Policy Content of Quantitative Minimum Wage Research. Proceedings of the Industrial Relations Research Association. Vol. 27, pp. 261-68. Retrieved: https://www.researchgate.net/publication/301346784_The_Policy_Content_of_Quantitative_Minimum_Wag e_Research. Access: 19.01.2018.

14. Gradstein M., Justman M., Meier V. (2005). The Political Economy of Education. Implications for Growth and Inequality. The MIT Press, Massachusetts Institute of Technology. Retrieved: http://www.amazon.com/ThePolitical-Economy-Education-Implications/dp/0262072564\#reader_0262072564. Access: 26.11.2017.

15. LETA (2017). Currently 60 \% Latvian Employers Face a Labour Shortage. News Agency LETA, 11 December 2017. Retrieved: http://nra.Iv/latvija/231270-sobrid-ar-darbaspeka-trukumu-saskaras-jau-60-latvijasuznemeju.htm. Access: 21.01.2018.

16. LETA (2018). A New Regulation is Expected to Attract from 200 to 300 Foreign Employees a Year. Retrieved: http://www.delfi.Iv/news/national/politics/ar-jaunu-regulejumu-plano-piesaistit-no-200-lidz-300viesstradniekiem-gada.d?id=49713727. Access: 05.02.2018.

17. Livingstone D., Guile D., et al., (2012). The Knowledge Economy and Lifelong Learning: A Critical Reader. Rotterdam: Sense Publishers. p. 334.

18. McKenzie P. (2001). How to Make Lifelong Learning a Reality: Implications for the Planning of Educational Provision in Australia. International Handbook on Lifelong Learning. Ed. D. Aspin, J. Chapman, M. Hatton,

Y. Sawano. Dordrecht; Boston: Kluwer Academic Publishers.

19. Ministry of Economics the Republic of Latvia (2016). Report on Economic Development in Latvia. Riga, June 2016. Retrieved: https://www.em.gov.Iv/files/tautsaimniecibas_attistiba/2016_jun.pdf. Access: 17.12.2017.

20. Ministry of Economics the Republic of Latvia (2017). Relaxed Terms for the Attraction of Foreign Labour - a Solution to the Lack of Labour in some Professions. Retrieved: https://www.em.gov.Iv/lv/jaunumi/14946atviegloti-nosacijumi-augsti-kvalificetu-specialistu-piesaistei-no-arvalstim-risinajums-darbaspekatrukumam-atseviskas-profesijas. https://www.em.gov.lv/lv/jaunumi/14946. Access: 16.01.2018.

21. National Development Plan of Latvia for 2014-2020 (NDP) (2012). Retrieved: http://www.varam.gov.lv/lat/darbibas_veidi/tap/lv/?doc=13524. Access: 16.11.2017.

22. Saeima of the Republic of Latvia (2002). Immigration Law. Adopted 31.10.2002. Retrieved: https://likumi.lv/doc.php?id=68522. Access: 23.01.2018.

23. Sannikova A. (2014). Economic Aspects of Lifelong Learning in Latvian Regions. In "Society, Integration, Education. Proceedings of the International Scientific Conference", May 23th - 24th, 2014, Value II, pp. 197-206. Rezekne Higher Education Institutions. Rezekne, Latvia, pp. 197-206 ISSN-1691-5887.

24. Sannikova A., Grizane T., Dobele A. (2017). Demand for and Supply of Higher Education in Latvia // Economic Science for Rural Development 2017, Latvia, Jelgava, 27.04.2017-28.04.2017. Jelgava: LLU, pp. 204-212. ISBN 978-9984-48-261-3. ISSN 1691-3078. ISSN 2255-9930 on line.

25. Warhust Cr., Thompson P. (2012). Mapping Knowledge in Work: Proxies or Practicels?. In "The Knowledge Economy and Lifelong Learning. A Critical Reader". Livingstone University of Toronto, Canada, University of London, UKD.W. P. O. Box 21858, 3001 AW Rotterdam, Netherlands, pp. 43-56.

26. World Economic Forum (2017). The Global Competitiveness Report 2017-2018. Retrieved: http://www3.weforum.org/docs/GCR2016-2017/05FullReport/TheGlobalCompetitivenessReport20162017_FINAL.pdf. Access: 02.02.2018.

27. Young M. (2012). Education, Globalization and the "Voice of Knowledge”. The Knowledge Economy and Lifelong Learning: A Critical Reader. D.W. Livingstone, D. Guile (Eds.) Rotterdam: Sense Publishers, pp. 335-348. 